Eduardo Gutiérrez-Abejón ${ }^{1,2}$ Francisco Herrera-Gómez ${ }^{1,3}$ Ignacio J. AyestaránMartínez ${ }^{1}$ Francisco Javier Álvarez ${ }^{1,4}$

\title{
Trend in the use of topical ocular anti-infectives in a region of Spain between 2015 and 2019: a population-based registry study
}

'Pharmacological Big Data Laboratory, Faculty of Medicine, University of Valladolid, Valladolid, Spain.

${ }^{2}$ Technical Direction of Pharmaceutical Care, Gerencia Regional de Salud de Castilla y León, Valladolid, Spain.

${ }^{3}$ Nephrology, Hospital Virgen de la Concha, Zamora, Spain.

${ }^{4}$ CEIm, Hospital Clínico Universitario de Valladolid, Valladolid, Spain.

\section{Article history}

Received: 14 August 2020; Revision Requested: 16 September 2020; Revision Received: 19 September 2020; Accepted: 21 September 2020; Published: 26 October 2020

\begin{abstract}
Objectives. This study presents the use and trends of use of topical ocular anti-infectives into a European population in the current decade (2015 to 2019) with an analysis of concomitant use with other ocular drugs, considering distribution by age and gender.

Patients and Methods. A population-based registry study was carried out to assess the ocular anti-infectives use from 2015 to 2019. All dispensations of these medicines at pharmacies in the largest region of Spain, Castile and León, was accessed. The number of packages dispensed, the percentage of the population under treatment, diagnosis, and the concomitant use with other ocular medicines was observed. For all analyses, the population distribution by age and gender was considered.
\end{abstract}

Results. An average of 198,000 packages of topical ocular anti-infectives were dispensed annually to $5.38 \%$ of the population, and more commonly for women than for men (5.83\% vs. $4.91 \%$ ). Children and the elderly used more these medicines. Tobramycin, alone or in combination, accounted for more than $68 \%$ of the total consumption (135,000 packages per year), and was the most widely used anti-infective in almost all identified diagnoses. Conjunctivitis (50.12\%), and stye (11.51\%) were the most frequent diagnoses. The consumption of ocular anti-infectives increased by 8.23\% from 2015 to 2019, and more among men than in women.

Conclusions. Our findings show that the most used topical ocular anti-infective was tobramycin, in accordance with the clinical practice guidelines recommendations. However, ocular infections are sometimes treated empirically, especially conjunctivitis.

Key words: drug utilization, topical ocular anti-infectives, ophthalmic infections.

Correspondence:

Eduardo Gutiérrez-Abejón

Pharmacological Big Data Laboratory, Faculty of Medicine,

University of Valladolid, Valladolid, Spain.

Phone: +34 983423077

E-mail: egutierreza@saludcastillayleon.es
Tendencia en el uso de antiinfecciosos tópicos oculares en una región de España entre 2015 y 2019: un estudio de registro basado en la población

\section{RESUMEN}

Objetivos. Evaluar el uso y tendencia de consumo de antiinfecciosos tópicos oftálmicos en una población europea entre 2015 y 2019, analizando el uso concomitante de otros medicamentos oculares y considerando la distribución por sexo y edad.

Pacientes y Métodos. Se ha realizado un estudio de registro basado en la población sobre el uso de antiinfecciosos tópicos oculares entre 2015 y 2019. Se han tenido en cuenta todas las dispensaciones realizadas en farmacias en Castilla y León. Se ha evaluado el número de envases dispensados, el porcentaje de población en tratamiento, el diagnóstico y el uso concomitante con fármacos oftálmicos. Para todos los análisis se tuvo en cuenta la distribución por sexo y edad.

Resultados. Anualmente se dispensaron de media 198.000 envases de antiinfecciosos tópicos oculares al 5,38\% de la población, con mayor consumo en mujeres que en hombres (5,83\% vs. 4,91\%). El uso de estos medicamentos fue mayor en niños y en ancianos. La tobramicina, sola o en combinación supuso más del 68\% del consumo (135.000 envases anuales), y fue el antiinfeccioso más utilizado en la mayoría de los diagnósticos. La conjuntivitis $(50,12 \%)$, y el orzuelo $(11,51 \%)$ fueron los diagnósticos más frecuentes. El consumo de antiinfecciosos oculares aumentó en un 8,23\% de 2015 a 2019, siendo mayor en hombres que en mujeres.

Conclusiones. Los resultados muestran que el antiinfeccioso más utilizado fue la tobramicina, en consonancia con las recomendaciones de las guías de práctica clínica. No obstante, en ocasiones, las infecciones oculares son tratadas de forma empírica, especialmente la conjuntivitis.

Palabras clave: utilización de medicamentos, antiinfecciosos tópicos oculares, infecciones oftálmicas. 


\section{INTRODUCTION}

Ocular infections are a worldwide health and economic problem [1], which, in the absence of an adequate treatment can cause vision loss and even blindness [2]. The most common ocular infection is still acute conjunctivitis, accounting for about $1 \%$ of primary care consultations. Conjunctivitis is very frequent in adults, and in 50 to $75 \%$ of cases bacteria are the cause [3], as for other common ocular infections, such as keratitis, blepharitis, endophthalmitis and dacryocystitis [4]. Such infections require treatment using topical ocular anti-infectives, easily administered in eye drops and at high concentrations $[1,5]$. However, frequent and inappropriate use of these medications can develop antibiotic resistance [2].

According to the data published in our country before 2010, consumption of topical ocular anti-infectives was almost 6 million packages per year and a trend toward increase was perceivable (8\% from 2004) [1], but incompletely understood. This study aimed to clarify the use of these medicines and its trends into a European population in the current decade (2015 to 2019), with an analysis of concomitant use with other ocular drugs, and by considering distribution by age and gender.

\section{MATERIAL AND METHODS}

An epidemiological population-based registry study was carried out between 2015 and 2019 to evaluate the use of topi- cal ocular antiinfectives into the population of Castile and León, adhering current guidelines when real-world data is presented, specifically RECORD (Reporting of studies Conducted using Observational Routinely-collected Data) recommendations [6].

According to the Anatomical Therapeutic Chemical classification (ATC) [7], the use of subgroups S01A (i.e., anti-infectives) and S01C (i.e., anti-inflammatory agents and anti-infectives in combination) was studied (Table 1). Information on the use of these medicines was obtained from the Castile and León pharmaceutical care database CONCYLIA [8] that retrieve all dispensations of medicines to the population covered by the Spanish health insurance system (2,376,717 in 2015 and 2,323,770 in 2019).

Dispensation was assumed equivalent to consumption. Distribution by age and gender was considered for all calculations concerning the following variables: 1) packages consumed, 2) frequency of consumption of topical ocular anti-infectives, 3) diagnosis and 4) concomitant use of ocular anti-infectives with other ocular medicines.

Percentages with their corresponding 95\% confidence interval and means accompanied with their standard deviation (SD) are presented. T-Student test (t) was used to evaluate differences between continuous variables and Chi-square test $\left(\chi^{2}\right)$ for differences between categorical variables, and Cochran-Armitage Test (Z) to evaluate trends of medicines use. The level of statistical significance was set at $p \leq 0.05$. SPSS version 24.0 was used for all analyses.

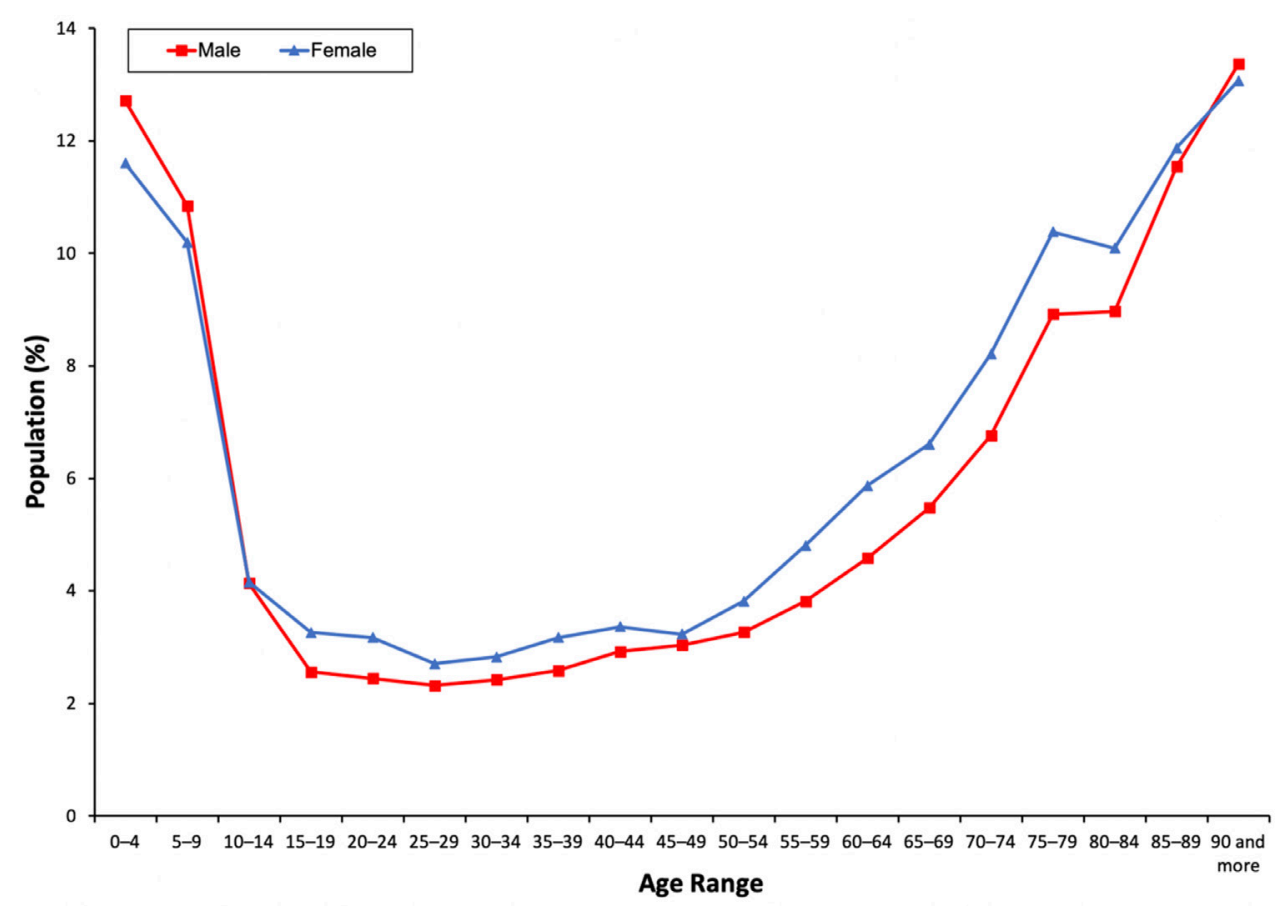

\begin{tabular}{l|l} 
Figure 1 & Frequency of topical ocular anti-infectives use by gender and age group.
\end{tabular} 
\begin{tabular}{|l|l}
\hline Table 1 & Evolution of topical ocular anti-infectives use in Castile and León (2015 - 2019).
\end{tabular}

\begin{tabular}{|c|c|c|c|c|c|}
\hline & \multicolumn{5}{|c|}{ Population using topical ocular anti-infectives \% (95Cl) } \\
\hline & 2015 & 2016 & 2017 & 2018 & 2019 \\
\hline Total & $5.17(5.14-5.2)$ & $5.29(5.27-5.32)$ & $5.31(5.28-5.34)$ & $5.52(5.5-5.55)$ & $5.59(5.56-5.62)$ \\
\hline Male & $4.65(4.61-4.69)$ & $4.79(4.75-4.83)$ & $4.85(4.81-4.89)$ & $5.06(5.02-5.1)$ & $5.19(5.15-5.23)$ \\
\hline \multirow[t]{2}{*}{ Female } & $5.67(5.63-5.71)$ & $5.79(5.74-5.83)$ & $5.75(5.71-5.79)$ & $5.97(5.93-6.01)$ & $5.98(5.94-6.03)$ \\
\hline & $\chi^{2}=1646.76 ; p=0.001$ & $\chi^{2}=1715.241 ; p=0.001$ & $\chi^{2}=1579.54 ; p=0.001$ & $\chi^{2}=1599.867 ; p=0.001$ & $\chi^{2}=1737.104 ; p=0.001$ \\
\hline \multicolumn{6}{|l|}{ Packages average per patient } \\
\hline Total & $1.55 \pm 1.39$ & $1.58 \pm 1.53$ & $1.6 \pm 1.56$ & $1.6 \pm 1.64$ & $1.58 \pm 1.53$ \\
\hline Male & $1.54 \pm 1.44$ & $1.56 \pm 1.61$ & $1.57 \pm 1.6$ & $1.58 \pm 1.7$ & $1.57 \pm 1.59$ \\
\hline \multirow[t]{2}{*}{ Female } & $1.57 \pm 1.34$ & $1.6 \pm 1.46$ & $1.61 \pm 1.52$ & $1.61 \pm 1.59$ & $1.6 \pm 1.48$ \\
\hline & $t=-3.644 ; p=0.001$ & $t=-4.356 ; p=0.001$ & $t=-4.317 ; p=0.001$ & $t=-3.605 ; p=0.001$ & $t=-2.896 ; p=0.001$ \\
\hline \multicolumn{6}{|l|}{ Drug use (\% Population/Packages) } \\
\hline Tobramycin + dexamethasone & $2.2 / 72,868$ & $2.23 / 75,250$ & $2.19 / 75,387$ & $2.25 / 78,466$ & $2.25 / 77,195$ \\
\hline Tobramycin & $1.72 / 52,228$ & $1.81 / 55,023$ & $1.94 / 58,771$ & $2.18 / 66,094$ & $2.25 / 68,098$ \\
\hline Antibiotics combination ${ }^{\mathrm{a}}$ & $0.38 / 10,697$ & $0.38 / 10,712$ & $0.32 / 8,826$ & $0.32 / 9,107$ & $0.31 / 8,645$ \\
\hline Chlortetracycline & $0.31 / 8,350$ & $0.33 / 9,015$ & $0.33 / 9,091$ & $0.35 / 9,757$ & $0.36 / 9,916$ \\
\hline Gentamicin & $0.26 / 7,250$ & $0.25 / 6,973$ & $0.24 / 6,571$ & $0.24 / 6,779$ & $0.25 / 6,885$ \\
\hline Ciprofloxacin & $0.25 / 8,759$ & $0.26 / 9,099$ & $0.24 / 8,411$ & $0.2 / 6,959$ & $0.18 / 6,439$ \\
\hline Fusidic acid & $0.29 / 7,861$ & $0.25 / 6,870$ & $0.23 / 6,229$ & $0.19 / 5,104$ & $0.17 / 4,644$ \\
\hline Ofloxacin & $0.17 / 6,123$ & $0.17 / 6,341$ & $0.19 / 7,124$ & $0.19 / 6,293$ & $0.19 / 6,206$ \\
\hline Erythromycin & $0.14 / 3,801$ & $0.15 / 4,181$ & $0.16 / 4,534$ & $0.19 / 5,360$ & $0.22 / 6,131$ \\
\hline Moxifloxacin & $0.15 / 5,281$ & $0.18 / 6,015$ & $0.18 / 6,266$ & $0.18 / 6,129$ & $0.17 / 5,671$ \\
\hline Azithromycin & $0.1 / 3,218$ & $0.1 / 3,451$ & $0.09 / 3,066$ & $0.09 / 3,069$ & $0.07 / 2,721$ \\
\hline Tobramycin + Diclofenac & $0.09 / 2,359$ & $0.11 / 2,883$ & $0.07 / 1,917$ & $0 / 6$ & $0 / 0$ \\
\hline Oxytetracycline & $0.04 / 1,127$ & $0.04 / 1,174$ & $0.05 / 1,540$ & $0.05 / 1,583$ & $0.05 / 1,503$ \\
\hline Aciclovir & $0.01 / 132$ & $0.03 / 871$ & $0.04 / 1,540$ & $0.04 / 1,698$ & $0.04 / 1,578$ \\
\hline Chloramphenicol & $0.02 / 709$ & $0.01 / 388$ & $0.01 / 297$ & $0.01 / 274$ & $0.01 / 296$ \\
\hline Norfloxacin & $0 / 10$ & $0 / 10$ & $0 / 15$ & $0 / 42$ & $0 / 63$ \\
\hline
\end{tabular}

a Neomycin/gramicidin/polymyxin B. Abbreviations: 95Cl, confidence interval

\section{RESULTS}

From 2015 to 2019, around one million packages of topical ocular anti-infectives was consumed, with an average of more than 198,000 annually. Overall, these findings show that $5.38 \%$ of the population was treated with ocular anti-infectives each year and consumed an average of $1.58 \pm 1.53$ packages. Women consumed these medicines more frequently than men (5.83\% vs. $4.91 \%, \chi^{2}=8185.016, p=0.001$; Table 1$)$, and the highest consumption occurred in the 0 to 9 years age group and in groups of 80 years and more (Figure 1).

Tobramycin alone (Code ATC S01AA12) or in combination with dexamethasone (S01CA01) or diclofenac (S01CC01) were consumed by more than $4 \%$ of population and represented al- most $68 \%$ of use of total topical ocular anti-infectives, with an average of more than 135,000 packages per year. Neomycin + gramicidin + polymyxin B (S01AA30) and chlortetracycline (S01AA02) were each consumed by $0.34 \%$ of the population. Fluroquinolones accounted for $10.11 \%$ of total use of topical ocular anti-infectives, with ciprofloxacin (S01AE03) as their main representative, being consumed by $0.23 \%$ of the population (Table 1).

In half the cases, the diagnosis was conjunctivitis, with 74\% bacterial origin, 24\% acute and only 1\% were considered viral. Other diagnoses were found such as stye (11.51\%), other ophthalmic diseases (5.34\%), postsurgical infections (5.1\%), blepharitis (4.74\%), eye damage (i.e., abrasion, erosion, laceration...) (3.57\%), and others with a lower incidence. It is impor- 


\begin{tabular}{|c|c|c|c|c|c|c|c|c|c|c|}
\hline & \multicolumn{10}{|c|}{ Ophthalmic diagnoses \% (95\% Cl) } \\
\hline & Conjunctivitis & No diagnosis & Stye & $\begin{array}{c}\text { Other } \\
\text { ophthalmic } \\
\text { diseases }\end{array}$ & $\begin{array}{l}\text { Postsurgical } \\
\text { infection }\end{array}$ & Blepharitis & Eye damage & Eye ulcer & Dacryocystitis & $\begin{array}{c}\text { Viral } \\
\text { infection }\end{array}$ \\
\hline $\begin{array}{l}\% \text { of total ophthalmic } \\
\text { diagnosis }\end{array}$ & $\begin{array}{c}50.12 \\
(49.68-50.57) \\
\end{array}$ & $\begin{array}{c}14.48 \\
(14.17-14.79) \\
\end{array}$ & $\begin{array}{c}11.51 \\
(11.23-11.8)\end{array}$ & $\begin{array}{c}5.34 \\
(5.14-5.54)\end{array}$ & $\begin{array}{c}5.1 \\
(4.9-5.3) \\
\end{array}$ & $\begin{array}{c}4.74 \\
(4.55-4.93)\end{array}$ & $\begin{array}{c}3.57 \\
(3.4-3.74)\end{array}$ & $\begin{array}{c}3.15 \\
(2.99-3.3)\end{array}$ & $\begin{array}{c}1.22 \\
(1.12-1.32)\end{array}$ & $\begin{array}{c}0.77 \\
(0.69-0.85) \\
\end{array}$ \\
\hline \multicolumn{11}{|c|}{ Drug use for diagnosis (\% Population) } \\
\hline $\begin{array}{l}\text { Tobramycin (alone and in } \\
\text { combination) }\end{array}$ & $\begin{array}{c}66.14 \\
(65.55-66.74)\end{array}$ & $\begin{array}{c}52.79 \\
(51.62-53.96)\end{array}$ & $\begin{array}{c}35.64 \\
(34.38-36.9)\end{array}$ & $\begin{array}{c}41.48 \\
(39.59-43.38)\end{array}$ & $\begin{array}{c}17.2 \\
(15.71-18.69)\end{array}$ & $\begin{array}{c}37.64 \\
(35.66-39.62)\end{array}$ & $\begin{array}{c}53.63 \\
(51.27-55.98)\end{array}$ & $\begin{array}{c}53.81 \\
(51.3-56.31)\end{array}$ & $\begin{array}{c}43.9 \\
(39.89-47.9)\end{array}$ & $\begin{array}{c}19.25 \\
(15.26-23.25)\end{array}$ \\
\hline Antibiotics combination $^{\mathrm{a}}$ & $\begin{array}{c}7.56 \\
(7.23-7.89)\end{array}$ & $\begin{array}{c}9 \\
(8.33-9.66)\end{array}$ & $\begin{array}{c}0.48 \\
(0.3-0.67)\end{array}$ & $\begin{array}{c}5.02 \\
(4.18-5.86)\end{array}$ & $\begin{array}{c}19.87 \\
(18.3-21.44)\end{array}$ & $\begin{array}{c}1.39 \\
(0.91-1.87)\end{array}$ & $\begin{array}{c}3.71 \\
(2.82-4.61)\end{array}$ & $\begin{array}{c}1.51 \\
(0.9-2.12)\end{array}$ & $\begin{array}{c}3.05 \\
(1.66-4.44)\end{array}$ & $\begin{array}{c}0.8 \\
(0.1-1.7)\end{array}$ \\
\hline Chlortetracycline & $\begin{array}{c}4.34 \\
(4.08-4.59)\end{array}$ & $\begin{array}{c}7.03 \\
(6.43-7.63)\end{array}$ & $\begin{array}{c}28.67 \\
(27.48-29.85)\end{array}$ & $\begin{array}{c}12.05 \\
(10.8-13.31)\end{array}$ & $\begin{array}{c}0.53 \\
(0.24-0.81)\end{array}$ & $\begin{array}{c}20.63 \\
(18.97-22.28)\end{array}$ & $\begin{array}{c}14.28 \\
(12.63-15.93)\end{array}$ & $\begin{array}{c}16.47 \\
(14.61-18.33)\end{array}$ & $\begin{array}{c}8.14 \\
(5.93-10.34)\end{array}$ & $\begin{array}{c}1.34 \\
(0.17-2.5)\end{array}$ \\
\hline Gentamicin & $\begin{array}{c}4.98 \\
(4.71-5.25)\end{array}$ & $\begin{array}{c}5.6 \\
(5.06-6.14)\end{array}$ & $\begin{array}{c}5.38 \\
(4.79-5.97)\end{array}$ & $\begin{array}{c}4.4 \\
(3.61-5.19)\end{array}$ & $\begin{array}{c}11.49 \\
(10.24-12.75)\end{array}$ & $\begin{array}{c}5.35 \\
(4.43-6.27)\end{array}$ & $\begin{array}{c}7.02 \\
(5.82-8.23)\end{array}$ & $\begin{array}{c}6.76 \\
(5.5-8.02)\end{array}$ & $\begin{array}{c}11.36 \\
(8.8-13.92)\end{array}$ & $\begin{array}{c}0.27 \\
(0.02-0.54)\end{array}$ \\
\hline Ciprofloxacin & $\begin{array}{c}5.05 \\
(4.78-5.33)\end{array}$ & $\begin{array}{c}4.75 \\
(4.25-5.24)\end{array}$ & $\begin{array}{c}2.01 \\
(1.64-2.38)\end{array}$ & $\begin{array}{c}6.14 \\
(5.22-7.07)\end{array}$ & $\begin{array}{c}9.47 \\
(8.32-10.62)\end{array}$ & $\begin{array}{c}3.66 \\
(2.89-4.42)\end{array}$ & $\begin{array}{c}4.47 \\
(3.49-5.44)\end{array}$ & $\begin{array}{c}5.58 \\
(4.43-6.73)\end{array}$ & $\begin{array}{c}10.68 \\
(8.19-13.17)\end{array}$ & $\begin{array}{c}3.21 \\
(1.42-4.99)\end{array}$ \\
\hline Fusidic acid & $\begin{array}{c}2.88 \\
(2.67-3.09)\end{array}$ & $\begin{array}{c}3.42 \\
(3-3.85)\end{array}$ & $\begin{array}{c}9.39 \\
(8.63-10.16)\end{array}$ & $\begin{array}{c}5.06 \\
(4.22-5.9)\end{array}$ & $\begin{array}{c}0.24 \\
(0.05-0.44)\end{array}$ & $\begin{array}{c}7.4 \\
(6.33-8.47)\end{array}$ & $\begin{array}{c}3.19 \\
(2.36-4.02)\end{array}$ & $\begin{array}{c}1.84 \\
(1.16-2.51)\end{array}$ & $\begin{array}{c}3.73 \\
(2.2-5.26)\end{array}$ & $\begin{array}{c}1.07 \\
(0.03-2.11)\end{array}$ \\
\hline Ofloxacin & $\begin{array}{c}3.76 \\
(3.52-4)\end{array}$ & $\begin{array}{c}4.46 \\
(3.98-4.95)\end{array}$ & $\begin{array}{c}0.66 \\
(0.45-0.88)\end{array}$ & $\begin{array}{c}4.4 \\
(3.61-5.19)\end{array}$ & $\begin{array}{c}9.71 \\
(8.55-10.88)\end{array}$ & $\begin{array}{c}1.78 \\
(1.24-2.33)\end{array}$ & $\begin{array}{c}1.92 \\
(1.27-2.56)\end{array}$ & $\begin{array}{c}2.3 \\
(1.54-3.05)\end{array}$ & $\begin{array}{c}6.27 \\
(4.31-8.23)\end{array}$ & $\begin{array}{c}1.34 \\
(0.17-2.5)\end{array}$ \\
\hline Erythromycin & $\begin{array}{c}2.19 \\
(2-2.37)\end{array}$ & $\begin{array}{c}3.49 \\
(3.06-3.92)\end{array}$ & $\begin{array}{c}12.37 \\
(11.51-13.23)\end{array}$ & $\begin{array}{c}6.49 \\
(5.54-7.44)\end{array}$ & $\begin{array}{c}0.77 \\
(0.42-1.11)\end{array}$ & $\begin{array}{c}16.23 \\
(14.72-17.74)\end{array}$ & $\begin{array}{c}5.92 \\
(4.81-7.03)\end{array}$ & $\begin{array}{c}4.92 \\
(3.84-6.01)\end{array}$ & $\begin{array}{c}3.56 \\
(2.06-5.05)\end{array}$ & $\begin{array}{c}2.41 \\
(0.85-3.96)\end{array}$ \\
\hline Moxifloxacin & $\begin{array}{c}1.06 \\
(0.93-1.19)\end{array}$ & $\begin{array}{c}5.09 \\
(4.57-5.6)\end{array}$ & $\begin{array}{c}0.11 \\
(0.02-0.19)\end{array}$ & $\begin{array}{c}8.73 \\
(7.64-9.82)\end{array}$ & $\begin{array}{c}29.38 \\
(27.58-31.18)\end{array}$ & $\begin{array}{c}0.7 \\
(0.36-1.04)\end{array}$ & $\begin{array}{c}1.92 \\
(1.27-2.56)\end{array}$ & $\begin{array}{c}1.97 \\
(1.27-2.67)\end{array}$ & $\begin{array}{c}4.24 \\
(2.61-5.86)\end{array}$ & $\begin{array}{c}1.87 \\
(0.5-3.25)\end{array}$ \\
\hline Azithromycin & $\begin{array}{c}1.39 \\
(1.24-1.54)\end{array}$ & $\begin{array}{c}1.6 \\
(1.3-1.89)\end{array}$ & $\begin{array}{c}0.43 \\
(0.26-0.6)\end{array}$ & $\begin{array}{c}3.82 \\
(3.09-4.56)\end{array}$ & $\begin{array}{c}1.09 \\
(0.68-1.5)\end{array}$ & $\begin{array}{c}2.48 \\
(1.84-3.12)\end{array}$ & $\begin{array}{c}0.7 \\
(0.3-1.09)\end{array}$ & $\begin{array}{c}0.66 \\
(0.25-1.06)\end{array}$ & $\begin{array}{c}1.53 \\
(0.54-2.51)\end{array}$ & $\begin{array}{c}0.53 \\
(0.2-0.76)\end{array}$ \\
\hline Oxytetracycline & $\begin{array}{c}0.36 \\
(0.28-0.43)\end{array}$ & $\begin{array}{c}1.68 \\
(1.38-1.98)\end{array}$ & $\begin{array}{c}4.55 \\
(4.01-5.1)\end{array}$ & $\begin{array}{c}1.62 \\
(1.14-2.11)\end{array}$ & $\begin{array}{c}0.04 \\
(0.01-0.08)\end{array}$ & $\begin{array}{c}2.39 \\
(1.77-3.02)\end{array}$ & $\begin{array}{c}2.73 \\
(1.96-3.5)\end{array}$ & $\begin{array}{c}1.97 \\
(1.27-2.67)\end{array}$ & $\begin{array}{c}1.69 \\
(0.65-2.74)\end{array}$ & $\begin{array}{c}0.27 \\
(0.02-0.54)\end{array}$ \\
\hline Aciclovir & $\begin{array}{c}0.12 \\
(0.07-0.16)\end{array}$ & $\begin{array}{c}0.78 \\
(0.58-0.99)\end{array}$ & $\begin{array}{c}0.05 \\
(0.01-0.1)\end{array}$ & $\begin{array}{c}0.39 \\
(0.15-0.63)\end{array}$ & $\begin{array}{c}0.08 \\
(0.02-0.12)\end{array}$ & $\begin{array}{c}0.04 \\
(0.01-0.07)\end{array}$ & $\begin{array}{c}0.12 \\
(0.01-0.23)\end{array}$ & $\begin{array}{c}1.77 \\
(1.11-2.43)\end{array}$ & $\begin{array}{c}0.17 \\
(0.01-0.33)\end{array}$ & $\begin{array}{c}67.65 \\
(62.91-72.39)\end{array}$ \\
\hline Chloramphenicol & $\begin{array}{c}0.14 \\
(0.09-0.19)\end{array}$ & $\begin{array}{c}0.27 \\
(0.15-0.39)\end{array}$ & $\begin{array}{c}0.18 \\
(0.07-0.29)\end{array}$ & $\begin{array}{c}0.35 \\
(0.12-0.57)\end{array}$ & $\begin{array}{c}0.08 \\
(0.02-0.12)\end{array}$ & $\begin{array}{c}0.22 \\
(0.03-0.41)\end{array}$ & $\begin{array}{c}0.41 \\
(0.11-0.71)\end{array}$ & $\begin{array}{c}0.46 \\
(0.12-0.8)\end{array}$ & $\begin{array}{c}1.36 \\
(0.42-2.29)\end{array}$ & - \\
\hline Norfloxacin & $\begin{array}{c}0.04 \\
(0.01-0.06)\end{array}$ & $\begin{array}{c}0.04 \\
(0.01-0.06)\end{array}$ & $\begin{array}{c}0.07 \\
(0-0.14) \\
\end{array}$ & $\begin{array}{c}0.08 \\
(0.01-0.15)\end{array}$ & $\begin{array}{c}0.04 \\
(0.0-0.08) \\
\end{array}$ & $\begin{array}{c}0.09 \\
(0.02-0.16)\end{array}$ & - & - & $\begin{array}{c}0.34 \\
(0.05-0.52) \\
\end{array}$ & - \\
\hline
\end{tabular}

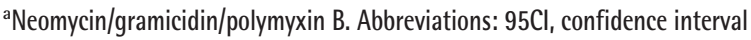

tant to note that in $14 \%$ of cases there was no specific diagnosis in the patient's medical record (Table 2). No significant differences were found between men and women.

Tobramycin alone or in combination was consumed by 3 -fifths of the population for the conjunctivitis treatment and was the most widely used anti-infective in almost all diagnoses. Tetracyclines (chlortetracycline and oxytetracycline) were mainly used in cases of stye $(33.22 \%)$ and Neomycin + gramicidin + polymyxin $B$, and fluoroquinolones, especially moxifloxacin, in postsurgical infections. On the other hand, as is to be expected, acyclovir was the most widely used anti-infective in viral infections (67.65\%) (Table 2).

During the covered period the use of ocular anti-infectives was increased by $8.23 \%(Z=30.26, p<0.0001,5.17 \%$ in 2015 vs. $5.38 \%$ in 2019), with an increase of $11.64 \%$ in men $(Z=50.21$, $p<0.0001,4.65 \%$ in 2015 vs. $4.91 \%$ in 2019 ) and of $5.49 \%$ in women $(Z=60.43, p<0.0001,5.67 \%$ in 2015 vs. $5.83 \%$ in 2019) (Table 1). Furthermore, users took $1.48 \pm 0.95$ different ocular medicines, with higher values in men than in woman (1.5 vs. $1.46, t=6.28, p=0.001)$, and represented by anti-inflammatory 
agents (Subgroup S01B, 11.67\%), decongestants and antiallergics (S01G, 7.38\%), antiglaucoma preparations and myotics (S01E, 4.85\%), and mydriatics and cycloplegics (S01X, 2.68\%).

\section{DISCUSSION}

Between 2015 and 2019 an increase in the use of topical ocular anti-infectives in Castile and León, the largest region of Spain, was noted. Indeed, more than 5\% of the population were under treatment with these medicines, with an increase in use among men, although a higher consumption was noted among women compared to men. As expected, conjunctivitis was the most common diagnosis among the population. In addition, a concomitant use with other ocular medicines was noted, especially anti-inflammatory agents and decongestants, and antiallergics.

Our findings show a higher use of ocular topical anti-infectives in children and the elderly, being consistent with the prevalence data found [3]. In addition, higher use of tobramycin is consistent with available evidence showing this anti-infective as a first-line medication in acute bacterial conjunctivitis [9]. Fluoroquinolones, especially ciprofloxacin, neomycin + gramicidin + polymyxin B, and azithromycin, are also considered first-line treatments. Indeed, the rest anti-infectives analyzed in this study are considered currently as second-line medications due to the appearance of microbial resistance (i.e., erythromycin, fusidic acid, etc.) [10] or due to safety concerns (e.g., chloramphenicol, tetracyclines) $[5,11]$. In this sense, the use of chlortetracycline in different diseases, especially in stye, is surprising, when tetracyclines are reserved for the treatment of infections secondary to Trachoma [5]. On the other hand, the low use of antivirals may be explained by the fact that more than $90 \%$ of viral conjunctivitis are caused by human adenoviruses and antivirals are not recommended for their treatment [12], while less than $4.8 \%$ are caused by Herpes simplex virus, and topical acyclovir is recommended [9].

Importantly, no all ocular anti-infectives are approved for all types of infections. These medicines are indicated for bacterial conjunctivitis, few ones for keratitis, and none for endophthalmitis [2].

The fact that $74 \%$ of the conjunctivitis diagnosed were bacterial origin and 14\% of anti-infectives were not prescribed for a specific diagnosis, suggests that treatment is often empirical. This may be because a bacterial origin is commonly indistinguishable from viral origin at the first consultation: physicians prescribe preemptively antibiotics in 95\% of cases and re-evaluate patients thereafter [3], even if an important proportion of these infections are self-limited without treatment [9].

Finally, with the considerations of an observational study and the limits of the database accessed that did not contain information on consumption of the medicines assessed in hospitals and in other settings (e.g., private practice) accounting for less than $3 \%$ of the population, our findings show a significant increase in the use of topical ocular anti-infectives between
2015 and 2019 in our region, that is represented basically by tobramycin in accordance with current recommendations. The profile of trends is different from that observed in the use of systemic antibiotics whose are also more and more used in recent years [13]. Our findings reinforces the idea that mostly ocular infections are treated empirically $[3,9]$, leading to an increased risk microbial resistance, treatment failure, and limit of future therapeutic options [1].

\section{ACKNOWLEDGMENTS}

The authors thank the Technical Direction of Pharmaceutical Care of Gerencia Regional de Salud de Castilla y León for access to CONCYLIA database.

\section{FUNDING}

None to declare.

\section{CONFLICTS OF INTEREST}

The authors declare that they have no conflicts of interest.

\section{REFERENCES}

1. García S, Mori P, López A, Alou L, Martínez D, Ramos C, et al. Impact of the consumption of ophthalmic topical antibiotics. Rev Esp Quimioter. 2010;23(4):201-205. PMID: 21191559

2. Bertino JS. Impact of antibiotic resistance in the management of ocular infections: the role of current and future antibiotics. Clin Ophthalmol. 2009;3:507-521. PMCID: PMC2754082

3. Andersson J, Hofsli M, Gade UL, Heegaard S, Pottegård A. Use of topical ocular antibiotics in young children: a Scandinavian drug utilization study. Acta Ophthalmol. 2018;96(8):789-794. PMID: 29885649

4. Teweldemedhin M, Gebreyesus $H_{1}$ Atsbaha AH, Asgedom SW, Saravanan M. Bacterial profile of ocular infections: a systematic review. BMC Ophthalmol. 2017;17(1):212. PMID: 29178851

5. Gaynor BD, Chidambaram JD, Cevallos V, Miao Y, Miller K, Jha HC, et al. Topical ocular antibiotics induce bacterial resistance at extraocular sites. Br J Ophthalmol. 2005;89(9):1097-1099. PMCID: PMC1772818

6. Benchimol El, Smeeth L, Guttmann A, Harron K, Moher D, Petersen I, et al, RECORD Working Committee. The REporting of studies Conducted using Observational Routinely-collected health Data (RECORD) statement. PLoS Med. 2015;12(10):e1001885. PMCID: PMC4595218

7. WHO Collaborating Centre for Drug Statistics Methodology. ATC/ DDD Index [Internet]. [cited 2020 Aug 12]. Available from: https:// www.whocc.no/atc_ddd_index/

8. CONCYLIA. Sistema de Información de Farmacia. Gerencia Regional de Salud de Castilla y León. Valladolid, Spain: Junta de Castilla y León. [Internet]. Available from: http://www.saludcastillayleon.es/ 
portalmedicamento/es/indicadoresinformes/concylia

9. Azari AA, Barney NP. Conjunctivitis: a systematic review of diagnosis and treatment. JAMA. 2013;310(16):1721-1729. PMCID: PMC4049531

10. Duncan $\mathrm{K}_{1}$ Jeng BH. Medical management of blepharitis. Curr Opin Ophthalmol. 2015;26(4):289-294. PMID: 26058027

11. Bremond-Gignac D, Chiambaretta F, Milazzo S. A European Perspective on Topical Ophthalmic Antibiotics: Current and Evolving Options. Ophthalmol Eye Dis. 2011;3:29-43. PMCID: PMC3661455

12. Alfonso SA, Fawley JD, Alexa Lu X. Conjunctivitis. Prim Care. 2015;42(3):325-345. PMID: 26319341

13. Simó Miñana J. Utilización de medicamentos en España y en Europa. Aten Primaria. 2012;44(6):335-347. PMCID: PMC7025249 